\title{
In Regard to Bozkurt et al.
}

To the Editor,

I read the article by Bozkurt and Şahin (1) with great interest. I have some points of concern related to this case report.

First, the authors have stated that painful erections lasted for about 1 hours after adding olanzapine $2.5 \mathrm{mg}$ /day. However, there was no comment regarding the number of attacks or the time of attacks. I believe that it is essential to determine whether periods of priapism occur during the day or the night in a 9-year-old boy because of possible physiological nocturnal erections in the peripubertal interval.

Second, in this case, priapism attacks were not observed by a health professional. Pain during erections or the color of the penis may lead us to a diagnosis of priapism; however, I believe that it should be clarified by an observation in the hospital. In addition, there are case reports of priapism with methylphenidate treatment $(2,3)$. It would be safer to observe the patient for a few hours after the initiation of methylphenidate in case of recurrence of priapism.

Finally, the authors have stated that other organic causes of priapism were excluded. However, the details of the examination were not mentioned in the article. I believe that the details of any radiological evaluation performed should be mentioned. This is because the diagnosis and treatment of priapism are not very clear for this age interval and there are only a few guidelines in the pediatric urology literature (4).

\section{Mete Özkıdık}

Clinic of Urology, Şanlıurfa Training and Research Hospital, Şanlıurfa, Turkey

\section{Anar İbrahimov}

Department of Urology, Ankara University School of Medicine, İbni Sina Hospital, Ankara, Turkey

\section{REFERENCES}

1. Bozkurt H, Şahin S. Olanzapine-induced Priapism in a Child with Asperger's Syndrome. Balkan Med J 2017;34:85-7.

2. Kelly BD, Lundon DJ, McGuinness D, Brady CM. Methylphenidate-induced erections in a prepubertal child. J Pediatr Urol 2013;9:1-2.

3. Esnafoglu E, Demir EY. Hallucination and priapism associated with methylphenidate usage: Two case reports. Indian J Psychiatry 2017;59:386-7.

4. Donaldson JF, Rees RW, Steinbrecher HA. Priapism in children: a comprehensive review and clinical guideline. J Pediatr Urol 2014;10:11-24.

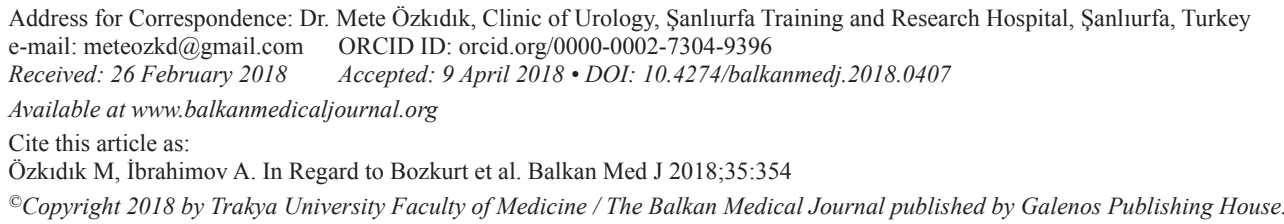

\section{In Reply to Özkıdık et al.}

To the Editor

We read the letter that criticizes our previous report published in Balkan Medical Journal. Commentaries to the letter are as noted below respectively (1).

Firstly, information regarding the medical and psychiatric history of this child case was taken from mother and we unfortunately did not have the chance to observe the penil erection attacks in a clinical setting. So we reported this pediatric case based on the mother's subjective observations. Those painless erections were only associated with olanzapine but not with any other factors or periods like day or night and resolved spontaneously after ceasing the treatment. According to mother, her son has never experienced such like these penil erections leading her to cease the drug. However we agree that information about the number of attacks should have been indicated in the case report.

Secondly, we already stated that methylphenidate does not seem to cause priapism since the case benefited from methylphenidate without any side effect except loss of appetite. Naranjo algorithm for olanzapine rather than methylphenidate also classed the adverse reaction as "most probably" (1). Additionally, the case kept using methylphenidate while priapism resolved after ceasing olanzapine.

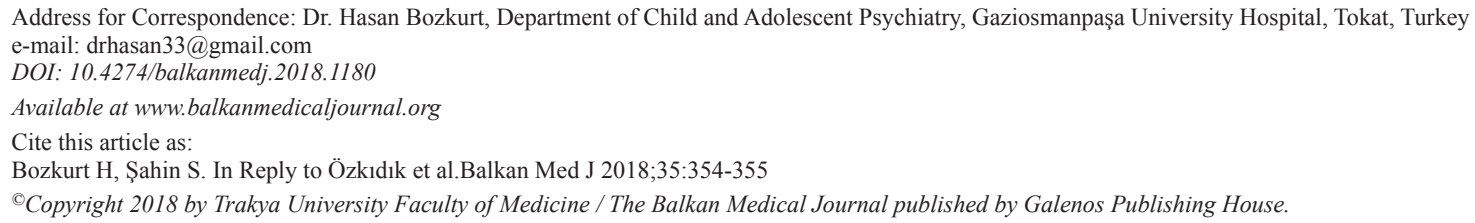


The commonest causes of priapism in children are reported to be sickle cell disease $(65 \%)$, leukaemia $(10 \%)$, trauma $(10 \%)$, idiopathic (10\%), and pharmacologically induced (5\%) (2). We excluded these conditions with medical history and blood work in the present case. However radiological evalution like colour duplex ultrasonography is usually helpful for distinguishing ischaemic and non-ischaemic priapism during attacks and also helpful in guiding treatment. As stated above, we could not directly observe the prapism attacks, so radiological examination was not thought to make a contribution on diagnosis and treatment of our case report (3).

\section{Hasan Bozkurt, Serkan Şahin}

Department of Child and Adolescent Psychiatry, Gaziosmanpaşa University Hospital, Tokat, Turkey

\section{REFERENCES}

1. Özkıdık M, İbrahimov A. In Regard to Bozkurt et al. Balkan Med J 2018;35:354.

2. Naranjo CA, Busto U, Sellers EM, Sandor P, Ruiz I, Roberts EA, et al. A method for estimating the probability of adverse drug reactions. Clin Pharmacol Ther 1981;30:23945 .

3. Donaldson JF, Rees RW, Steinbrecher HA. Priapism in children: a comprehensive review and clinical guideline. J Pediatr Urol 2014;10:11-25. 